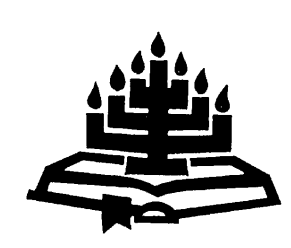

\title{
Natuurwetenskaplike kennis en die Woord van God
}

\author{
P.H. Stoker \\ Skool vir Fisika \\ Potchefstroomkampus \\ Noordwes-Universiteit \\ POTCHEFSTROOM \\ E-mail: pieter.stoker@nwu.ac.za
}

\begin{abstract}
Natural science knowledge and the Word of God

The Greek philosophers denied that true knowledge could be obtained by observing the sensory world. True knowledge related only to things that were unchanging, immutable. For Pythagoras and Plato that meant, first of all, mathematics. Following the Pythagorean-Platonian tradition, many early scientists held that mathematical order represented the most real and certain aspect of the world. Galileo moved science away from ordinary observations toward mathematical reasoning. For Galileo the abstract, idealistic world was the real world. However, in the natural world, which is anarchic and far from equilibrium, energy transfer represents a source of order, creativity and growth. Also, new assemblages of species appeared after large numbers of species had gone extinct in earth's history. These surges of energy transfer cannot be described by linear time. Scripture does not reveal to us the workings of nature - we can only learn about it through scientific methods. However, those who do not acknowledge God's supernatural acts of creation are forced to search for other answers through their own thinking about the origin, purpose, meaning and interrelatedness of everything. It is shown that the successive acts of creation in Genesis 1 are reconcilable with current knowledge of the natural sciences.
\end{abstract}

\section{Opsomming}

\section{Natuurwetenskaplike kennis en die Woord van God}

Die Griekse wysgere het ontken dat ware kennis deur sensoriese waarneming verkry kan word. Ware kennis het slegs betrekking gehad op onveranderlikhede in die natuur. Vir Pithagoras en Plato was wiskunde die primêre bron van kennis. In 
navolging van die Pithagoras-Plato-tradisie het wetenskaplikes wiskundige ordening van die wêreld as die mees reële en sekerste kennis aanvaar. Galileo het die natuurwetenskappe laat wegbeweeg van alledaagse waarnemings na abstrakte wiskundige beredenering. Vir Galileo was hierdie abstrakte geïdealiseerde wêreld die werklike wêreld. Stelsels in die natuur wat onbeheerbaar en ver van ewewig is, word dikwels die bron van 'n nuwe ordelikheid, kreatiwiteit en groei. So 'n oorgang kan nie in terme van lineêre tyd beskryf word nie. Nog voorbeelde van sulke oorgange is wanneer 'n groot aantal spesies uitgewis word en vervang word met 'n nuwe versameling spesies. God openbaar nie in sy Woord kennis ten opsigte van die werking van die natuur nie - dit kan bekom word deur wetenskaplike metodes. Diegene wat egter nie God se bonatuurlike skeppingshandelings aanvaar nie, moet deur hulle denke antwoorde vind omtrent die oorsprong, doel, betekenis en samehang van alles. Opeenvolgende skeppingsgegewens in Genesis 1 blyk ooreen te stem met huidige natuurwetenskaplike kennis.

\section{Inleiding}

Die bewering word dikwels gemaak dat die histories-letterlike benadering van Genesis 1-3 die Bybel in konflik bring met bewese wetenskaplike feite. Hierdie bewering het sy oorsprong in die geloof dat die wetenskap reeds bewys het dat die aarde miljarde jare oud is, terwyl fossiele van diere gevind is wat miljoene jare oud is. Ook die sterrestelsels moet miljarde jare oud wees, omdat lig van ver sterre miljarde jare neem om die aarde te bereik (Vorster, 2009:97).

Die aanvaarding van dinge wat die wetenskap reeds sou bewys het, bring dadelik die vraag na vore hoe die verskillende bronne van kennis beoordeel en hulle waarde bepaal moet word. 'n Verdere vraag is wat God ons omtrent die skepping leer en hoe sy skepping vanuit sy Woord en vanuit die wetenskap verstaan moet word. Hierdie vrae word in hierdie artikel ondersoek.

Die Natuurwetenskappe erken God nie as Skepper nie en aanvaar slegs dit wat sintuiglik waargeneem en logies-kousaal uitgeredeneer kan word. Volgens die klassieke Griekse wysbegeerte is die kennis wat uit die sintuiglike wêreld verkry word nie seker nie, omdat hierdie wêreld gedurig verander. Ware kennis kan slegs verkry word van dinge wat nie verander en met tyd vergaan nie. Vir die Griekse wysgere Pithagoras en Plato was die onveranderbare basis van kennis in wiskunde geleë (Pearcey \& Thaxton, 1994:131). 


\section{Die Pithagoras-Plato-tradisie}

\subsection{Pithagoras se getalleleer}

Die Griekse wysgeer Pithagoras wat in die sesde eeu voor Christus geleef het, was oortuig dat ordelikheid in die heelal deur verhoudings van getalle bepaal word. Sy geloof in die rol van getalle in die natuur is versterk deur byvoorbeeld die rol van getalle in musiek. 'n Oktaaf word byvoorbeeld deur die verhouding 2:1 in toonhoogtes gekenmerk.

Die moderne Fisika verkry getalle deur eksperimentele metings. In fisika word waarnemings omtrent die wêreld dus in terme van getalle geskryf. Dit gee aan moderne Fisika 'n onveranderlike basis, want verhoudings van getalle verander nie. Die heelgetalle drie gedeel deur vier bly altyd 'n driekwart - 'n rasionele getal. Aangesien wiskunde met getalle werk, het die moderne Fisika wiskunde as die basis vir die beskrywing van die veranderende natuur aanvaar (Pearcey \& Thaxton, 1994:126 e.v.). Die resultate van hierdie wiskundige beskrywing van die natuur word dikwels tot ware kennis verhef soos blyk uit die gravitasiewet van Newton.

\subsection{Plato se Ideëleer}

Gedurende die eerste vier eeue van die Griekse kultuur (circa 600 tot 200 v.C.) was die wêreld waarin die mens geleef en sintuiglik waargeneem het vir die Griekse wysgere die werklikheid wat verstaan moet word. Hierdie werklikheid, vol lewe en veranderlikheid en sintuiglik waargeneem, is aanvanklik materialisties beskryf. Plato (427-347 v.C.) het benewens hierdie materialistiese benadering ook 'n nie-materialistiese beskouing in sy filosofie ontwikkel, naamlik dat ware kennis meer is as die werklikheid wat ons met ons sintuie waarneem.

Vir Plato was die ware werklikheid in 'n wêreld buite die sintuiglike waarneming geleë, naamlik in 'n wêreld van volmaakte abstrakte idees en vorms. Sy ideëwêreld het bestaan in wiskundige verwantskappe en vaste meetkundige strukture en vorms wat nie sintuiglik waargeneem kan word nie - 'n wêreld wat slegs deur ons verstand geken kan word (Pearcey \& Thaxton, 1994:124). Die wêreld wat ons deur sintuiglike waarnemings ervaar, was vir hom 'n wêreld in wording (of becoming) (Davies, 1993:35).

Aristoteles (384-322 v.C.), 'n student van Plato, het nie Plato se ideëwêreld aanvaar nie. Hy het sy teorie van beweging op alledaagse ervaring gebou, byvoorbeeld dat 'n kar op 'n horisontale pad sal 
gaan staan indien ons dit nie bly stoot nie. Aristoteles se teorieë het 'n werklike wêreld beskryf waarin beweging tot rus kom (Pearcey \& Thaxton, 1994:128). Galileo (1564-1642 n.C.), daarenteen, het wetenskap losgemaak van alledaagse waarnemings deur wiskundige beredenerings deel van wetenskaplike modelle te maak.

In die Middeleeue het die skolastici Aristoteles se denke by Christelike lerings aangepas. Aan die einde van die Middeleeue was Aristotelianisme die omvattende lewens- en wêreldbeskouing, en dit was vervat in die skolastiese onderrig by die meeste universiteite. Die wetenskaplike revolusie wat met die Renaissance begin het, het baie fasette van die Aristoteliaanse lewens- en wêreldbeskouing uitgedaag, veral in Sterrekunde en Fisika (Pearcey \& Thaxton, 1994: 61).

Galileo het die Aristoteliaanse wetenskap van die Middeleeue omvorm deur gebruik te maak van verstandelike abstraksies. Sy teorieë het nie beweging van werklike voorwerpe wat ons uit ervaring ken, beskryf nie. Sy teorieë het eerder denkbeeldige meetkundige voorwerpe beskryf - voorwerpe met volmaakte vorms (bv. 'n sfeer of 'n punt) - wat langs volmaakte bane beweeg op vlakke sonder wrywing, lugweerstand en atmosferiese druk. Hy het sodoende die fisiese wetenskappe tot 'n Pithagoras-Platoniese ideëleer geïdealiseer.

Die basiese kenmerke van 'n Aristoteliaanse natuurbeskrywing is kwaliteite en nie kwantiteite met 'n wiskundige benadering nie. 'n Rugbyspeler wat 'n drie moet verdoel, kan as voorbeeld dien. Volgens die Aristoteliaanse tradisie sal die beweging van die bal wat deur die pale geskop word, kwalitatief beskryf word. Die PithagorasPlato-benadering, sou weer daarop fokus om die beweging van die bal in vertikale en horisontale bewegings te ontbind. Swaartekrag bepaal die vertikale op-en afbeweging van die bal nadat dit geskop is, terwyl die horisontale beweging slegs deur lugweerstand verlangsaam word. Die samestelling van die twee bewegings is die baan van die bal nadat dit geskop is. Wiskundig is hierdie baan 'n parabool indien daar nie lugweerstand is nie.

\subsection{Tyd in fisiese teorieë}

Dit is aan Galileo te danke dat tyd, as 'n fundamentele meetbare grootheid, deel van die wetenskapsvorming geword het. Om beweging te kan bestudeer, moes Galileo van 'n tydeenheid met konstante duur gebruik maak. Hy het ook die gelykdurigheid (isochronisme) van die slingerklok ontdek en dit as tydeenheid gebruik. 
Hiermee het hy tyd as 'n abstrakte grootheid ontdek (Adam, 2004: 101), 'n grootheid vir die meting van tydsverloop (Stoker, 2008).

Nadat Galileo se werk bekend geword het, het filosowe en wetenskaplikes langsamerhand begin besef dat die gedrag van fisiese voorwerpe wiskundig beskryf kan word, met tyd as 'n onafhanklike veranderlike. Dit het gelei tot die idee dat natuurwette deur God daargestel is om sy skepping te orden. Dit was grootliks die filosofie van Descartes (verwoord in Discourse on method, 1637), wat gelei het tot die aanvaarding van die idee dat die mens in 'n heelal leef waarvan die werking deur natuurwette beheers word. Volgens Descartes moes 'n heelal wat deur vaste wette beheer word, deur dieselfde wette sedert die begin ontwikkel het na 'n nimmereindigende toekoms (Nickel, 2001:159). Die idee van 'n kosmiese evolusie het sy oorsprong dus by Descartes gehad.

Toe Isaac Newton (1642-1727) se Philosophiae naturalis principia mathematica in 1687 verskyn het, het kloktyd alreeds 'n houvas op die wetenskap en handel gehad en algemene veranderings in die sosiale lewe aangebring (Adam, 2004:29). Newton het die idee van kloktyd na die heelal uitgebrei. Deur die gebruik van kloktyd in die planetestelsel, kan byvoorbeeld met presiese noukeurigheid die tydstippe voorspel word waarop die vier mane van Jupiter agter die planeet sal verdwyn.

Newton se tyd is in wese wiskundig van aard. Die redusering van tyd tot ' $n$ wiskundige parameter beroof tyd van sy oorspronklike natuurlike en menslike inhoud en betekenis. Dit leer 'n mens niks omtrent die eie aard van tyd nie.

\subsection{Tyd in Einstein se algemene relatiwiteitsteorie}

Newton se heelal was 'n absolute ruimte waarin beweging in terme van absolute tyd beskryf is. Met die oorgang na die twintigste eeu het Newton se begrip van absolute ruimte en tyd absurde en teenstrydige resultate begin gee ten opsigte van die gedrag van ligseine en die beweging van materiële liggame (Feynman et al., 1965:15-3). Hierdie probleme is deur Einstein opgelos. Hy het nuwe tyd- en ruimtebegrippe vir sy relatiwiteitsteorie aanvaar (Feynman et al., 1965:17-1 e.v.). Einstein het tyd egter steeds gebruik as 'n wiskundige parameter wat fisies meetbaar is en in rigting omgekeer kan word (Feynman et al., 1965:17-4).

Einstein kon die teenstrydigheid in die eksperimentele resultate teoreties verreken deur te aanvaar dat ligsnelheid oral in die heelal 
dieselfde waarde het (nl. $3 \times 10^{8}$ meter per sekonde in 'n vakuum), en dat niks vinniger as dit kan beweeg nie (Feynman et al., 1965:159 ). Vir hierdie aanname bestaan daar geen ervaringsgrond nie, behalwe pragmaties - eksperimentele resultate word deur sy relatiwiteitsteorie korrek beskryf.

Einstein het deur sy algemene relatiwiteitsteorie ruimte afhanklik van gravitasiekrag gemaak. Sodanige koppeling van ruimte met gravitasiekrag is slegs moontlik in 'n heelal met 'n eindige grootte, wat helaas nie in ewewig is nie (Davies, 1993:46). Hubble se ontdekking van die rooiverskuiwing van spektraallyne van ver galaksies het hierdie probleem ondervang met 'n uitdyende heelal (Silk, 1980:48). Gevolglik moes die heelal 'n definitiewe begin gehad het met 'n oerknal sowat 14000 miljoen jaar gelede.

Volgens Einstein se relatiwiteitsteorie verloop tyd van plek tot plek verskillend, omdat tyd sowel van beweging as van gravitasiekrag afhang. Daar bestaan dus in beginsel geen rede waarom tyd nie ook sporadies anders as lineêr in 'n koördinaatstelsel sal verloop nie (Silk, 1980:321). Die revolusie wat Einstein in die paradigma van tyd begin het, is vandag nog nie afgehandel nie (Davies, 1995:33).

\subsection{Oerknalteorie}

Ook die oerknalteorie is in die Pithagoras-Plato-ideëwêreld gefundeer. Die wiskundige beskrywing van die oerknal is buite die sintuiglike (en eksperimentele) waarnemingsveld. Die basis van die wiskundige beskrywing is kennis verkry uit eksperimentele waarnemings in kernfisika.

Kosmologie is die studie van die grootskaalse samestelling van die heelal soos dit vandag waargeneem kan word. Die oerknalteorie voorsien aan die Kosmologie breë riglyne vir die evolusie en wording van die heelal (Davies, 1993:68). Hiervolgens moes die heelal sowat 14000 miljoen jaar gelede met 'n ontploffing begin het. Op grond van fisiese oorwegings moes die oermaterie in die ontploffing by 'n geweldige hoë temperatuur gewees het, waarna dit vinnig na buite uitgedy en gevolglik afgekoel het. Volgens die wiskundige beskrywing van die fisiese prosesse, het lig van die warm materie losgekom nadat die materie voldoende afgekoel het (Silk, 1980: 127).

Die oermaterie moes baie gou ná die ontploffing in elementêre materiedeeltjies, die boustene van atome, getransformeer het. Waterstof en 'n klein persentasie helium is gevorm (Silk, 1980:79). Hier- 
die waterstof- en heliumgasse het uitgedy en moes later groot gaswolke gevorm het waarin gravitasiekragte hierdie atome tot galaksies laat saamtrek het met hulle kenmerkende grootskaalse sterstrukture. Daar is verskillende fisiese modelle vir die vorming van galaksies en ook vir ons sonnestelsel. Tussen die modelle kan moeilik gekies word weens 'n gebrek aan eksperimentele waarnemings.

Die warmtestrale vanaf die oerknal het ook in die materieruimte uitgedy en afgekoel tot die mikrogolfstrale wat vandag waargeneem word. Hierdie strale verteenwoordig 'n temperatuur van 3 grade kelvin $\left(-270^{\circ} \mathrm{C}\right)$, wat 3 grade bo die absolute nulpunt van $-273^{\circ} \mathrm{C}$ is (Silk, 1980:78).

Dit is merkwaardig dat hierdie strale deur die materie (die sterre en sterrestelsels) in die hemelruim vasgevang word. Daar bestaan geen logiese rede hiervoor nie. Dieselfde verskynsel word met die Foucault-slinger waargeneem. Soos die aarde roteer, swaai die Foucault-slinger steeds op 'n vaste vlak ten opsigte van die sterreruimte en nie ten opsigte van die son wat baie nader aan die aarde as die sterre is nie. Hierdie verskynsel, naamlik dat die materie van die sterreruimte in die geheel plaaslike beweging bepaal, is bekend as Mach se beginsel (Polkinghorne, 1991:90, 91) - 'n beginsel wat die mens waarneem, maar nie verstaan nie. Dit dui egter daarop dat die heelal 'n strukturele eenheid is.

\section{Huidige kennis van die heelal}

\subsection{Strukturele eenheid van die heelal}

Ons melkwegstelsel (galaksie) met sy miljarde sterre vorm 'n strukturele eenheid vanaf die binnekerngebied met sy swartgataktiwiteite (gravitasiekolkaktiwiteite; "black hole" activities) tot die buitenste sterre. Die sterre in 'n galaksie word met mekaar gekoppel deur magnetiese, elektriese en gravitasievelde, asook plasmawinde vanaf die binnegebied. Die melkwegstelsel is as strukturele eenheid ook fisies met ons galaksiegroep gekoppel en dié weer met supergroepe. Almal is aan mekaar gekoppel deur middel van magnetiese, elektriese en gravitasievelde.

Die mens se kennis van die heelal is nog baie onvolledig, maar dit kan tog met redelike sekerheid gesê word dat, indien die heelal stukkie vir stukkie opgebou was, dit eers sy funksionele eenheid sou verkry het nadat al die dele daar was. Die heelal kon deur die bonatuurlike handelinge van God tot 'n geheel geskape gewees het, 
wat volgens die Bybelverhaal, in die vierde skeppingsdag voltooi is (die sterre was dadelik sigbaar - Gen. 1:16-18). Dit kon egter ook oor duisende miljoene jare vanaf die oerknal geleidelik gevorm het, volgens die Kosmologie.

\subsection{Die grootte van die heelal}

Die grootte van die heelal word nie verkry deur maatbande tussen hemelliggame uit te lê, soos ons op aarde kan doen nie. Posisies van sterre naaste aan die aarde verskil met 'n klein hoek na ses maande. Die aarde beweeg in ' $n$ amper sirkelbaan om die son. $\mathrm{Na}$ ses maande is die aarde met twee maal die afstand na die son vanaf sy eerste posisie verplaas, dit is dus twee maal 150 miljoen kilometer. Vanuit hierdie diametrale posisies op die baan van die aarde om die son kan die afstand van die ster deur driehoeksmeetkunde bereken word, net soos landmeters afstande op aarde bepaal. Hierdie afstande na naburige sterre word in parsek bereken. (Een parsek is die afstand vanaf die aarde wanneer 'n hoekverandering van twee boogsekonde na 'n ster na ses maande waargeneem word.) Een parsek is sowat 309 duisend miljoen miljoen miljoen kilometer (Silk, 1980:29).

Afstande na sowat 5000 sterre word deur hierdie driehoeksmeetkundige metode bepaal. Die hoekverskil word te klein om afstande na sterre verder weg meetkundig noukeurig te bereken. Die afstande na hierdie sterre word deur verskillende skaalgraderingsmetodes verkry, onder andere deur die afname in helderheid namate die afstand toeneem. Die afstande na naby sterre dien steeds as ykmaat (Silk, 1980:29 e.v.).

Die enorme grootte van die heelal en sy strukturele en funksionele eenheid met al sy miljarde sterrestelsels as deelstelsels van hierdie eenheid, getuig van God se almag en die oneindigheid van sy Wese - of die heelal nou ook al vanaf 'n oerknal deur natuurwette tot stand gekom het, of deur goddelike bonatuurlike handelinge.

\subsection{Ouderdom van die heelal}

Parsek is die maat wat sterrekundiges gebruik vir afstande in die sterreruim. Op grond van Einstein se relatiwiteitsteorie word hierdie afstande ook in ligjare omgereken. Hierdie omrekening berus op die aanname dat ligsnelheid oral in die heelal dieselfde as op aarde is en dat dit nie deur beweging, versnelling of gravitasiekrag verander nie. Hierdie veronderstelling beteken dat lig vanaf ' $n$ bron steeds met dieselfde ligsnelheid as op aarde verby 'n mens sal beweeg, 
hetsy jy stilstaan ten opsigte van die bron, of selfs as jy met ligsnelheid na die ligbron toe beweeg.

Die omrekening van afstande van parsek na ligjare op grond van Einstein se aanname, beteken dat lig vanaf die verste sigbare sterrestelsels tot 9000 miljoen jaar neem om die aarde te bereik en dat die oerknal 14000 miljoen jaar gelede plaasgevind het. Die aarde se ouderdom van 4000 miljoen jaar, wat deur die radioaktiewe verval van onder andere uraanisotope bereken word, sluit by hierdie ouderdomme van sterrestelsels aan.

Sowel ligsnelheid as vervaltyd van radioaktiewe stowwe is waardes wat in terme van kloktyd vandag op aarde gemeet word. Die aanname dat hierdie waardes oral in die heelal vanaf die gryse verlede oor miljarde jare steeds geldig is, beteken die aanvaarding van ' $n$ lineêre tydsverloop oral en altyd. Die geldigheid van ouderdomme wat op grond van hierdie aannames bereken word, hang af van die geldigheid van hierdie aannames - wat nie bewys kan word nie.

\section{Is die ouderdomsgetal van die aarde 'n feit?}

Die aarde se ouderdom van 4000 miljoen jaar word dikwels as 'n feit gestel (bv. Vorster, 2009:97). Daar bestaan egter verskillende fisiese waarnemings waaruit die ouderdom van die aarde bereken word, waarvan radioaktiewe verval een is. Die nuutste ouderdomsberekening van die aarde word gedoen uit die afname in die aarde se magneetveld, waarvan die totale magnetiese energie elke 1500 jaar halveer (Coe, et al., 1995:687). Daarvolgens kan die aarde nie ouer as 20000 jaar wees nie. Ander fisiese waarnemings lewer ouderdomme hoër as 20000 jaar. Dit is menslik onmoontlik om te besluit watter metode die werklike ouderdom gee, want ons kan die verlede slegs ken uit wat ons vandag waarneem.

Die woord feit word in baie betekenisse gebruik. Een van die betekenisse is dat iets wat waar is, ' $n$ feit is. Wanneer is ' $n$ veronderstelde feit waar? Die antwoord op hierdie vraag hou die mens al vir etlike millenniums besig.

Soms word feite bepaal wanneer dit deur almal aanvaar word. ' $n$ Voorbeeld hiervan is die spelreëls, woordbetekenisse en reëls van die grammatika wat opgevoede persone gebruik wanneer hulle praat en skryf (vgl. Woordeboek van die Afrikaanse Taal, 1956). Op grond van die feit dat die evolusieteorie vandag in die media verkondig word en deur baie mense aanvaar word as dié wyse waardeur alles ontstaan het, beskou sekere mense die fisiese evolusie 
vanaf die oerknal en die biologiese evolusie vanaf die mikroskopiese lewe tot vandag, as (bewese) feite.

Tot en met die agtiende eeu het bioloë geglo dat lewende dinge spontaan uit nie-lewende dinge ontstaan. Daar is herhaaldelik waargeneem dat maaiers, wurms en vlieë in dooie en verrotte vleis voorkom. Daar is ook waargeneem dat klein organismes, naamlik mikrobes, in gekookte vleis ontstaan, selfs al word dit in 'n fles verseël. Daaruit is afgelei dat die mikrobes nie van buite uit die lug kom nie (Fry, 2000). Die sogenaamde spontane ontstaan van lewe uit nie-lewende materiale was in die agtiende eeu vir bioloë 'n feit op grond van herhaaldelike waarnemings. Sedert 'n reeks eksperimente in die negentiende eeu deur die Franse chemikus Louis Pasteur, word dit vandag nie meer as 'n feit beskou nie. Pasteur het onteenseglik bewys dat lewe nie spontaan uit nie-lewe ontstaan nie.

Sedert die publikasie van Darwin se boek oor die evolusieleer, On the origin of species, in 1895 is die debat oor die ontstaan van lewe uit nie-lewende materiale weer aan die gang gesit. Indien alles met 'n oerknal begin het, moes lewe uit materie gekom het nadat die aarde voldoende afgekoel het. Hierdie materie kon geen lewe bevat het nie.

\section{Wat openbaar die Woord van God?}

Die primêre doel van God se Woord is nie om die mens te vertel hoe die natuur werk nie. God openbaar nie aan die mens dinge wat self deur natuurwetenskaplike metodes uitgevind kan word nie. Deur sy Woord wil God inligting van dinge gee wat ons nie op 'n ander wyse kan bekom nie - soos dinge dat

- God alles geskep het;

- dat God man en vrou na sy Beeld geskep het:

- dat die mens in sonde geval het;

- dat God ná die sondvloed sy verbond met die mens hernu het;

- dat die mens deur Christus se lyding en kruisiging met God versoen is; en

- dat die verloste mens kragtens die opstanding en hemelvaart van Christus, die hoop het op 'n nuwe verheerlikte lewe na sy wederkoms en herskepping van die hemel en die aarde. 
Hierdie eenmalige gebeurtenisse kan nie deur natuurwetenskaplike metodes ontdek word nie. Dit lê op die vlak van die geloof.

Die reformatoriese lewens- en wêreldbeskouing sluit hierby aan asook by Calvyn se eerste vraag in sy Kategismus: "Wat is die vernaamste doel van die menslike lewe?" Sy antwoord: "Om kennis te verkry van God, wat ons geskep het." (Calvyn, 1937.) Hierdie kennis van God word in die eerste artikel van die Nederlandse Geloofsbelydenis opgesom: "God is ewig, onbegryplik, onsienlik, onveranderlik, oneindig, almagtig, volkome wys, regverdig, goed en die aller oorvloedigste fontein van alles wat goed is." Deur dít wat ons by wyse van natuurwetenskaplike metodes van God se skepping ontdek, leer ons God ken as 'n Skepper - 'n Skepper wat elke ding kunstig en met oorleg ontwerp het, wat elke ding in die skepping, ook die verskillende manifestasies van tyd, aan sy doel laat beantwoord.

Die menslike lewe en kultuur is in die Skrif gefundeer. Die reformatoriese belydenis stel hierdie Christelike beskouing kragtig teenoor ongeloof en die wêreldse (sekulêre) beskouing oor die betekenis van lewe en die oorsprong en doel van alles wat bestaan, insluitend die mensdom en sy poging om sonder God sy eie heil te bewerk.

\section{Natuurwetenskaplike kennis en die skeppingsverhaal}

\subsection{Bonatuurlike skeppingsdade}

Genesis 1 verhaal van God se skeppingsdade wat volgens die Natuurwetenskappe bonatuurlik is, omdat dit wat tot stand gekom het, nie deur natuurwette bepaal is nie. Bonatuurlike skeppingsdade kan daarom net in die geloof aanvaar word. Hebreërs 11:3 stel dit soos volg: "Deur die geloof verstaan ons dat die wêreld deur die woord van God toeberei is, sodat dinge wat gesien word, nie ontstaan het uit sienlike dinge nie." Die mens vind deur wetenskaplike metodes geen bewyse van bonatuurlike skeppingsdade nie.

Deur eksperimentele waarnemings verkry die fisiese natuurwetenskappe (wat die natuur wiskundig beskryf by wyse van gedagtemodelle of "ideë") kennis van God se skepping. Hierdie skepping is deur God, volgens sy openbaring in sy Woord, tot stand gebring. Nadat God hemel en aarde geskep het (Gen. 1:1), het God lig, die ruimtelike strukture van die aarde (landmassas, oseane, lug en wolke), die planteryk, asook die son, maan en sterrehemel in die eerste vier skeppingsdae gevorm. Stem die opeenvolging van hierdie skeppingshandelinge ooreen met huidige natuurwetenskaplike kennis? In 
navolging van van twee kommentare (Calvyn, 1970; Lee, 1979) word hierdie vraag kortliks beantwoord.

Die hemel en aarde wat God in die begin geskep het (Gen. 1:1), is in die Ou Testament en ten dele ook in die Nuwe Testament, 'n omskrywing vir dit wat bestaan. Dit het dieselfde betekenis as heelal, waarvoor daar in die Hebreeus nie 'n afsonderlike woord was nie (Aalders, 1949:77).

"In die begin het God die hemel en die aarde geskep" (Gen. 1:1, Heb. 1:10). "Die begin" is die begin van die skepping. Die skepping was dus nie altyd daar nie - dit is nie ewig nie (Calvyn, 1970:28, par.1). "Die begin" moet daarom ook die begin van tyd wees, wat deel van die skepping is en wat saam met die hemel en die aarde geskep is. Want voor "die begin", was daar slegs God se ewigheid en nog geen skepping nie. Die skepping was nie deel van God se ewigheid nie (Lee, 1979: par. 1:1 e.v.).

"En die aarde was woes en leeg, en die duisternis was op die wêreldvloed, en die Gees van God het gesweef op die waters." (Gen. 1:2.) Met die klem op die aarde, was dit wat geskep is, ongevormd ("woes"). Daar was geen strukture in die massas nie, want daar was nog nie wette waaraan die massas onderwerp is nie waar daar nie orde is nie, kan daar ook geen wet wees nie. Die ongeordenheid word ook deur die "waters" aangedui. Die aarde was tot in sy diepste dieptes ongevormd en donker (Calvyn, 1970:29, par. 2).

Daar is twee betekenisse van die Hebreeuse woord sweef: die Gees van God was werksaam op die massas om dit te deurdring, die wesenskrag uit te brei en dit met wesenskrag te bevrug (Lee, 1979, par. 1:2l), óf die Gees sweef daaroor om dit te ondersteun (Calvyn: 1970:29, par. 2; kyk ook Ps. 104:30 e.v.). Alles was in duisternis gehul omdat daar nog geen lig was nie.

\subsection{Skepping van lig}

"En God het gesê: Laat daar lig wees! En daar was lig." (Gen. 1:3.) Hiermee getuig God dat Hy lig in sy hand het en dat Hy deur sy bevel, lig uit die rou materie wat Hy alreeds in Genesis 1:1 uit niks geskep het, te voorskyn geroep het. Die lig het nie uit die son of sterre gekom nie, want God het dit nog nie geskep nie (Calvyn, 1970:30-31, par. 3). Dit was die eerste stap om deur sy Krag aan die rou materiaal struktuur te gee deur lig te skep (Lee, 1979: par.1:3b). 
Vandag word lig in koue materie (halfgeleiers) opgewek, onder andere die sogenaamde LUD's (Liguitstraaldiodes - LED). Hierdie lig word vandag in kommunikasienetwerke gebruik. Ligseine word byvoorbeeld deur optiese kabels in die Internet van een punt na 'n volgende oor lang afstande gestuur. Aan die ontvangskant word die ligseine weer deur liggevoelige diodes omgesit in elektriese seine (Stix, 2001). Konvensionele gloeilampe vir huishoudelike gebruik word vandag deur energiebesparende gloeilampe vervang, lampe waarin lig deur koue materie uitgestraal word (Savage, 2000). 'n Ander voorbeeld van 'n liggevoelige element is die CCD (chargecoupled device) wat in plat rekenaarskerms en digitale kameras gebruik word.

Volgens die Natuurwetenskappe ontstaan hierdie lig in materie se atoomstrukture. Lig wat uit die atoomstrukture kom, het die vermoë om sy (lig)energie weer aan die atoomstrukture terug te gee. Hierdie potensiaal tot wisselwerking tussen materie en lig, moes die Gees van God aan die ongevormde materie van Genesis 1:2 voorsien het, sodat Hy lig op die eerste skeppingsdag te voorskyn kon roep.

Eers op die vierde skeppingsdag het Hy diskrete ligdraers in die hemelruim te voorskyn laat kom uit die oermaterie wat in Genesis 1:1 geskep is - hierdie ligdraers is te voorskyn geroep met "Laat daar ligte wees aan die uitspansel" (Gen. 1:14), en daarom was dit nie skepping uit niks nie (Lee, 1979. par. 1:16 e.v.). Lig self is nie nou te voorskyn geroep nie - dit het alreeds gebeur. Nou was dit slegs ligdraers in die hemelruim "om dag en nag van mekaar te skei", "om as tekens te dien" en "om lig op die aarde te gee" (Gen. 1:14; Calvyn, 1970:36, par. 14; Lee, 1979, par. 1:14a).

Die ligdraers (van die vierde skeppingsdag) se lig vul nou aan by die lig wat God in die eerste skeppingsdag te voorskyn geroep het. Die eerste lig het egter verspreid uit koue materie gekom terwyl dit nou ook vanuit warm stralende hemelliggame kom (Calvyn, 1970:36, par. 14). Hy het by die vorming van die son, nie aan die son die taak opgedra om met sy warmte die gras, plante en bome uit die aarde te laat opkom en met sy lig hulle te laat groei nie. Dit kon die lig van die eerste skeppingsdag alreeds gedoen het.

\subsection{Landmassas en see}

Op die derde skeppingsdag laat God "die waters onder die hemel (uitspansel) hulle op een plek versamel, sodat die droë grond sigbaar word. So het dit gebeur" (Gen. 1:9). "En God het die droë 
grond 'aarde' genoem, en die versameling van waters het Hy 'see' genoem. Toe sien God dat dit goed was." (Gen. 1:10.)

Die geologiese wetenskap het redelik onlangs (gedurende die sestigerjare van die vorige eeu) begin verstaan dat sogenaamde plaattektoniek die sleutel tot die bestaan van kontinente is (Ward \& Brownlee, 2000:202). Alfred Wegener het reeds in 1912 kontinentale dryf afgelei uit die waarneming dat die groot kontinente soos stukke van 'n legkaart by mekaar pas (Hamblin \& Chritiansen, 2004:482).

Landmassas bestaan uit materiaal van laer digtheid as die onderliggende mantel, waarop kontinente beweeg. Aanvanklik was die aarde 'n waterplaneet, waarna die landmassa bo die see-oppervlak uitgestyg het - eers as een superkontinent met see daaromheen. Daarna het die landmassa opgebreek en het as afsonderlike kontinente uitmekaar gedryf. Die geologiese wetenskap sien die uitstyg van landmassa om bo die see-oppervlak sigbaar word as 'n natuurlike proses wat met verloop van tyd plaasgevind het (Ward \& Brownlee, 2000). Hierteenoor openbaar God in sy Woord dat Hy landmassa ("droë grond") deur 'n bonatuurlike skeppingshandeling in die derde skeppingsdag te voorskyn laat kom het.

God het toe gesien dat dit goed was, ook die grense (wette) wat hy gestel het, waaraan die see en sy golwe onderworpe is (Lee, 1979, par. 1:10e; vgl. ook Job 26:10 \& 38:8-11; Ps. 104:5-9). Daarmee het God verseker dat lewe op aarde kan kom sonder dat dit deur die waters en storms van die see vernietig word. Ná die skeiding van land en see was die aarde nog leeg en onvrugbaar, maar God maak dit deur sy Woord vrugbaar (Calvyn, 1970:34-35, par. 11) deur gras, plante en bome uit die aarde te laat voortkom (Gen. 1:11-12). Hierdie handeling word afgesluit met die woorde: "Toe sien God dat dit goed was", met die betekenis dat God wette vir groei, vrug- en saadvorming en vir voortplanting van gras, plante en bome daargestel het (Lee, 1979, par. 1:11 e.v.). God het daarmee die ingeskape krag tot voortplanting en oorlewing aan die planteryk gegee (Calvyn, 1970:35, par. 11).

Die wonderbaarlike en onuitputlike rykdom aan verskeidenheid in die planteryk wat ons daagliks aanskou, getuig van die magtige grootheid, wysheid en goedheid van die Almagtige God. God het lig as ' $n$ inherente deel van materie op die eerste skeppingsdag te voorskyn geroep, voordat gras, plante en bome geskep is en voordat die son gemaak is. 


\subsection{Plantelewe is nie ex nihilo geskep nie}

In Genesis 1 kom die woord skep (bara) slegs by drie geleenthede voor. By elke geleentheid het God iets nuuts geskep, iets wat nog nie daar was nie: eerstens die materie van hemel en aarde (Gen. $1: 1$ ), tweedens die besielde lewe (lewende wesens, wat beweeg Gen. 1:21) en laastens die geestelike lewe van die mens (ewebeeld van God - Gen. 1:27). Plantelewe word op die derde skeppingsdag op God se bevel deur die aarde voortgebring (Gen. 1:11) en nie as iets wat uit niks geskep is nie. Die lewensbeginsel vir plantelewe moes daarom saam met materie geskep gewees het toe God hemel en aarde volgens Genesis 1:1 geskep het, sodat die aarde op die derde skeppingsdag plantelewe op God se bevel kon voortbring.

Plante wat op land groei, omskep chemiese elemente in die grond tot vorms wat as voedsel deur die liggaam van mens en dier opgeneem kan word. Miljoene bakterieë in die grond help plante hiermee. Vandag is daar ongeveer 40 miljoen bakterieë in 1 gram grond, en ' $n$ miljoen bakterieë in ' $n$ milliliter vars water. In totaal is daar $5 \times 10^{30}$ bakterieë op aarde, wat 'n groot gedeelte van die aarde se biomassa vorm (Subba Rao, 1999).

Die aarde het ook 'n verbasende herstelvermoë na droogtes, brande, natuurrampe en besoedeling deur die mens. Ook hier speel bakterieë as mikroskopiese organismes 'n beslissende rol.

Plante bepaal ook die vlak van die kweekhuisgas koolsuurgas in die atmosfeer. Wanneer die hoeveelheid koolsuurgas in die atmosfeer toeneem, word dit warmer en plante groei vinniger om meer koolsuurgas uit die atmosfeer te verwyder, sodat die vlak van koolsuurgas weer daal. Sodoende help plante dat die atmosfeer nie warmer word nie. Plante moes alreeds daar gewees het om die atmosfeer se temperatuur te reguleer toe die son as 'n ligdraer op die vierde skeppingsdag te voorskyn geroep is. So is voorkom dat die aarde vir organiese lewe soos plante, diere en mense te warm gebak word.

Koel oseane is nodig vir die groei van alge. Wanneer die bolaag van oseane te warm word, sal die warm water in die bolaag verhoed dat voedingstowwe vanaf die bodem van die oseane opwaarts styg om die alge te voed. Deur die persentasie koolsuurgas in die atmosfeer laag te hou, bly die bolaag koel en sorg alge vir sy eie voedingstowwe vanaf die seebodem en daardeur vir sy eie groei. Dit verseker 'n groot verskeidenheid lewe in die oseane (Schwartzman, 2002). Te warm oseane maak baie soorte lewe onmoontlik, onder meer dié van alge. Daarsonder sal koolsuurgas in die atmosfeer 
toeneem en die oseane warmer word. Water sal dan vinniger uit die oseane verdamp en deur die warm atmosfeer na die buitenste ruimtes ontsnap, totdat die aarde 'n droë planeet word soos sy buurplanete Mars en Venus. Daar is aanduidings dat water wel vroeër op Mars en Venus was. Hulle atmosfere is hoofsaaklik koolsuurgas. Op hierdie planete maak uiterstes in dag- en nagtemperature lewe onmoontlik.

\subsection{Die lewende aarde}

Daar word intellektueel skerp onderskei tussen lewelose en lewende materie - iets leef, of dit leef nie. Lewe kom in sy eenvoudigste vorm voor in 'n sel wat die eienskap het om spontaan in meer selle te verdeel. Indien die heelal uit die oerknal ontstaan het, moes die son, aarde en planete as lewelose materie, uit 'n kosmiese gaswolk gekondenseer het onder die werking van gravitasiekragte. Lewe moes dan uit hierdie materie gekom het nadat die aarde voldoende afgekoel het.

Die mees aanvaarde teorie vir die ontstaan van lewe uit nie-lewende materie is dat die bestanddele van die eerste lewende sel in 'n elektriese storm en in 'n atmosfeer sonder suurstof, onderling met mekaar verbind het. Dit kon tot dusver nie eksperimenteel bewys word nie - lewe kon (nog) nie eksperimenteel uit lewelose stowwe gemaak word nie. Volgens Darwin, het alle lewe op aarde voortgespruit uit hierdie eerste lewende sel, deur die werking van natuurlike seleksie (Mayr, 1991:140).

Volgens die fossielrekord was die eerste lewe bakterieë. Voor die sestigerjare van die vorige eeu, is geglo dat hierdie mikroskopiese lewe eers gekom het en daarna gesorg het vir die regte verhouding van die gasse (stikstof, suurstof en koolsuurgas) in die atmosfeer, en vir die regte soutkonsentrasie in die oseane sodat standhoudende lewe op aarde en in die oseane moontlik kan wees. Sedertdien aanvaar al hoe meer natuurwetenskaplikes dat die aarde se eerste lewensvorme en die nodige fisiese eienskappe van die aarde se oppervlak, atmosfeer en oseane, saam ontwikkel (geëvolueer) het vir volhoubare lewe op die aarde (Schwartzman, 2002). Hierdie gedagte van 'n "lewende aarde" sluit aan by die bybelse skeppingsverhaal. Hiervolgens het God plantelewe (en bakterieë) eers te voorskyn geroep voordat Hy die son laat skyn het. Die seediere, voëls en landdiere wat God op die vyfde en sesde skeppingsdae geskep het, sou nie in die warm strale van die son kon oorleef het indien die samestelling van die atmosfeer en oseane nie vir lewe reg 
was nie. Daarom moes plantelewe eers daar gewees het voor die son, diere en die mens gekom het.

\section{Onbeheerbare prosesse in die natuur}

\subsection{Beheerbare en onbeheerbare dinamiese prosesse}

In die natuurwetenskappe word geleidelike veranderings onder ewewigstoestande in die laboratoriums en kweekhuise bestudeer. Hierdie bevindings word toegepas op nywerhede en boerderye in prosesse wat beheerbaar is. Net so is die gaarmaak van kos, die hardloop van 'n marathon of die bestuur van 'n motor prosesse wat die mens kan beheer. Hierdie oop termodinamiese prosesse voer energie op ' $n$ beheerbare wyse van buite af in. Dit is prosesse wat beheers verloop.

In die natuur kom daar egter onbeheerbare prosesse voor. Die atmosfeer kan rustig bly (in ewewig), maar van tyd tot tyd steek stormwinde of selfs orkane op met verwoestende gevolge - verskynsels wat wisselvallig en onbeheerbaar is. Dieselfde geld vir onbeheerbare verskynsels soos aardbewings en vulkaniese uitbarstings. In hierdie verskynsels is daar 'n groot hoeveelheid onbenutte (latente) energie, wat onbeheerbaar verkwis word (dissipative structures volgens Prigogine, 1980:84) om nuwe strukture te vorm. Die prosesse in hierdie onbeheerbare verskynsels is ver van ewewig af. Die bekende wette van die termodinamika geld nie vir hierdie prosesse nie. Prigogine (1980) het hierdie prosesse in die fisiese en chemiese sowel as in die biologiese en geologiese wetenskappe bestudeer en 'n wiskundige beskrywing vir hulle verlope gevind.

Volgens Peacocke (1996:10) is een van die merkwaardigste onlangse ontwikkelings in die natuurwetenskappe die waarneming dat baie dinamiese stelsels (fisies, chemies, biologies en geologies), van tyd tot tyd in hulle makroskopiese gedrag onbeheerbaar word. Professor Ilya Prigogine (1917-2003), 'n Belg, het die Nobelprys vir Chemie in 1977 ontvang vir sy bydrae tot termodinamika asook die fisiese en chemiese stelsels wat ver van ewewig is en tot onbeheerbare gedrag kan oorgaan.

Daar is dus twee formulerings van die natuurwette (Prigogine, 1980:212), die een vir beheerbare (ewewig-) prosesse en die ander vir onbeheerbare prosesse (ver van ewewig af). Albei kom in die natuur voor. Die formulerings van natuurwette is vir albei ewe fundamenteel. Natuurwette vir beheerbare prosesse kan met 'n lineêre verloop van tyd beskryf word. Prigogine (1980) het hom ten doel 
gestel om 'n beskrywing van tyd vir natuurwette te vind in prosesse wat ver van ewewig is en wat op onvoorspelbare tydstippe onbeheerbaar tot nuwe toestande groei.

\subsection{Katastrofisme}

'n Verdere voorbeeld van 'n onbeheerbare verskynsel is die waarneming dat bestaande biologiese spesies van tyd tot verdwyn en nuwe spesies in hulle plek te voorskyn kom. Dit is die resultaat van die navorsing van die Franse anatoom (ontleedkundige) Baron Georges Cuvier (1769-1832) in die laat agtiende eeu voordat Darwin die evolusieteorie in 1859 geformuleer het. Cuvier het aangetoon dat die bene van die uitgestorwe mammoete ('n prehistoriese olifant in Eurasië, gekenmerk deur sy besondere grootte, baie lang tande wat na bo gekrom is en sy goed-ontwikkelde liggaamshare) van die hedendaagse olifante verskil. Hy het daarom tot die onvermydelike gevolgtrekking gekom dat die mammoetspesie nie meer bestaan nie en dus moes uitgesterf het. Deur 'n uitgebreide studie van fossielneersetting in die Paryskom, het hy krisistye in die aarde se geskiedenis geïdentifiseer; tye waartydens 'n groot aantal spesies in 'n baie kort periode uitgewis is en waarna 'n nuwe versameling spesies weer ontstaan het (Leaky \& Lewin, 1999:41-42).

Voordat die Kambriese periode 542 miljoen jaar gelede volgens die geologiese tydskaal begin het, was daar slegs vegetatiewe mikroskopiese lewe op aarde. Anders gestel, dit was biologiese lewe wat uit onsigbare enkelselle bestaan het en slegs deur ' $n$ mikroskoop waarneembaar was. Dit het soos plante en mosse vermeerder. Op daardie geologiese tydstip het daar skielik, met 'n evolusionêre ontploffing, sigbare lewe gekom. Die fossielrekord toon aan dat met die Kambriese ontploffing al die filums (bouplanne) wat vandag op aarde is, hulle verskyning gemaak het. Die fossiele was almal van lewe op die seebodem.

Cuvier het bevind dat daar twee agtereenvolgende vernietigende krisisse (katastrofes) in die voorkoms van spesies was sedert die Kambriese ontploffing. $\mathrm{Na}$ elkeen van hierdie katastrofale vermindering van spesies, het 'n nuwe versameling biologiese spesies weer te voorskyn gekom. Op grond van hierdie waarnemings het Cuvier die biologiese geskiedenis van multisellewe, wat as die "Phanerosoïkum" (sigbare lewe) bekend is, in drie eras of tydperke met standhoudende biologiese lewe verdeel: die Paleosoïkum (antieke lewe) van 530 tot 225, die Mesosoïkum (middellewe) van 225 tot 65 miljoen, en die Sensoïkum (moderne lewe) van 65 miljoen jaar gelede tot vandag (Leaky \& Lewin, 1999:42). 
Cuvier het elke krisis in die bestaande biologiese lewe as 'n afsonderlike gebeurtenis gesien. Na elke vermindering het 'n nuwe versameling biologiese spesies gekom. Noag se vloed was volgens hom een van die twee vernietigende uitwissings (Leaky \& Lewin, 1999:42).

\section{Geleidelike veranderings}

Die waarnemings van Cuvier is bekend as katastrofisme, 'n teorie dat biologiese geskiedenis deur katastrofisme gekenmerk word. Hierdie teorie is deur wetenskaplikes in die algemeen aanvaar tot James Hutton (1726-1797) van Edinburgh dit in 1785 betwyfel het (Hamblin \& Christiansen, 2004:191). Hy en medewerkers het aanduidings gevind dat geologiese veranderings op aarde 'n langsame en geleidelike proses is, wat oor lang tydperke strek. Volgens Hutton kan geologiese gebeure in die verlede verklaar word deur dieselfde natuurlike, langsame prosesse soos ons dit vandag waarneem. Hierdie beginsel dat die prosesse van die verre verlede net so langsaam soos vandag plaasgevind het, is bekend as uniformitarisme.

Die Skotse geoloog Charles Lyell (1797-1875) het op die gedagtes van James Hutton in van sy driedelige publikasie, Principles of Geology (1830-1833), voortgebou. Sy uitgangspunt hierin is dat die geologiese prosesse wat ons vandag waarneem soos erosie deur wind en reën, asook aardbewings en vulkane, verantwoordelik is vir alle geologiese veranderings op die aarde en in sy geskiedenis. Hy aanvaar dat oor lang periodes klein veranderings opbou tot groot veranderings. Lyell se gedagtegang word saamgevat deur die stelling dat die hede die sleutel tot die verlede is. Dit beteken dat ons op grond van ons ervaring vandag, gebeurtenisse en prosesse in die verlede kan verstaan. Dit neem nie in aanmerking dat die mens se geologiese waarnemings oor 'n relatiewe kort leeftyd strek, met die gevolg dat daar baie geologiese gebeurtenisse in die verlede kon gewees het waarvan ons niks weet nie (Leaky \& Lewin, 1999:43).

Lyell se uniformitaristiese gedagtegang het geseëvier oor katastrofisme, wat gesien is as verskynsels met 'n godsdienstige (bybelse) grondslag. Uniformitarisme in geologie het aan Darwin die grondslag voorsien vir sy teorie van gradualisme in biologie, waarvolgens groot evolusionistiese veranderings voortspruit uit opeenvolgende klein veranderings oor lang tydperke onder die kragtige werking van natuurlike seleksie. Net soos Lyell die gedagte van katastrofale veranderings in geologie verwerp het, het Darwin enige spronge in die geleidelike vooruitgang in biologiese lewe verwerp. Spronge was vir Darwin die gevolg van 'n bonatuurlike inwerking op die natuurpro- 
sesse. Daar kan geen spronge wees in prosesse wat deur natuurlike seleksie gedryf word nie. Hiermee het Darwin enige bonatuurlike verklaring in enige natuurlike omgewing verwerp (Mayr, 1991:140).

Cuvier se waarnemings van 'n nuwe versameling spesies se verskyning na die uitwissing van die vorige spesies, het in die vroeë negentiende eeu tot baie geologiese werk in die Paryskom en elders in Europa gelei. Deur hierdie werk, is die drie eras of tydperke van Cuvier weer in onderskeie periodes onderverdeel, elkeen met 'n eiesoortige versameling biologiese spesies. Deur klimaatsveranderings kon spesies uitgesterf het, wat dan telkens deur die opkoms van 'n nuwe versameling spesies opgevolg is. Wat die nuwe samestellings spesies na 'n katastrofe gaan wees, kan nie voorspel word nie (Leaky \& Lewin, 1999:41).

Uit hierdie werk is die geologiese kolom met die sowat vyftien stratigrafiese lae saamgestel. Op grond van Lyell se werk is aanvaar dat die stratigrafiese lae van die kolom oor miljoene jare geleidelik en agtereenvolgens opgebou het. $\mathrm{Na}$ die ontdekking van radioaktiwiteit aan die einde van die negentiende eeu, is jaartalle aan die vormingsperiodes van die lae gegee (Hamblin \& Chritiansen, 2004:191 e.v.), asook aan die drie eras of tydperke van Cuvier. Die ouderdomme wat uit radioaktiewe verval bereken word, aanvaar 'n lineêre verloop van tyd, op sterkte van uniformitarisme en die PithagorasPlatoniese tradisie.

Die opeenvolging van die vyftien stratigrafiese lae verskil in verskillende gebiede van die wêreld. Deur indeksfossiele en mineralogie word lae in verskillende gebiede met periodes van die gestandaardiseerde geologiese kolom verbind. Ouderdomme van aardlae, wat deur argeologie en paleontologie ontbloot word, kan sodoende geologies bepaal word. Fossiele se ouderdomme word aanvaar as die ouderdomme van die aardlae waarin die fossiele gevind word. Die standaard geologiese kolom se waarde lê in die ordening van die waarnemings op verskillende kontinente, deur jaartalle aan sodanige waarnemings te verbind.

Die huidige vorm van die aarde se landmassas bied 'n momentopname van 'n proses van veranderings waaraan die aardkors onderhewig is. Dit is 'n proses waardeur berge opstyg en weer terugsak, waardeur seë oor landmassas uitbrei en weer terugtrek, waardeur kontinente verskuif, waardeur nuwe rotse deur vulkane vorm, en die bolaag van die aardkors deur wind en weer erodeer. Geologiese prosesse is 'n samespel van geleidelike voortgang en skielike katastrofes (Hamblin \& Chritiansen, 2004:190 e.v.). Deur slegs geleide- 
like veranderings te aanvaar, word vraagtekens op die betroubaarheid van die geologiese tydskaal (soos gestandaardiseer in die geologiese kolom) van miljoene tot miljarde jare geplaas. Die werklikheidsbetekenis van alle ouderdomsbepalings van die aarde en fossiele moet dus ook bevraagteken word.

\section{Epiloog}

Na die Renaissance was baie van die vroeë natuurwetenskaplikes nog onder die invloed van die middeleeuse denke dat God die waarheid is waardeur die werklikheid verstaan moet word. Hulle beskouing van die natuur was tweeledig: God het die wêreld met 'n wiskundige struktuur gemaak, en Hy het die mens met 'n verstand gemaak om daardie struktuur te verstaan. Hierdie twee beginsels tref ons onder andere by Kepler as sterrekundige en by Descartes as filosoof aan. Spoedig het die sukses van die wiskundige beskrywing van die fisiese natuur egter tot rasionalisme gelei en God het toeskouer geword (deïsme).

Met die aanvaarding van die Pithagoras-Plato-tradisie het baie van die vroeë wetenskaplikes geglo dat wiskundige ordening die mees reële en sekerste kennis van die wêreld is. Dit het tot die oortuiging gelei dat die wêreld volgens natuurwette verloop en God in die voortgang van die wêreld nie meer nodig is nie (Pearcey \& Thaxton, 1994:139).

Die mens bestudeer die natuur met beheerde laboratoriumeksperimente en pas hierdie bevindings op beheerbare prosesse in nywerhede toe. Natuurwette, in terme van beheerde prosesse, word met 'n lineêre verloop van tyd beskryf. Buite die laboratorium, in die vrye natuur en in die heelal, word verskynsels waargeneem wat nie volgens beheerde prosesse verloop nie. Hierdie prosesse het dikwels 'n groot hoeveelheid onbenutte energie wat in uitbarstings tot nuwe toestande en strukture kan lei. Prosesse in hierdie uitbarstings is onbeheerbaar en onvoorspelbaar. Ander fundamentele wette as die natuurwette vir beheerde prosesse geld vir hierdie prosesse wat wiskundig met chaosteorie beskryf word.

Onbeheerbare prosesse kom in baie dinamiese stelsels in die fisiese, chemiese, biologiese en geologiese natuur voor. Die mens verstaan nie die verloop van tyd in onbeheerbare dinamiese stelsels nie. Ouderdomme kan slegs met 'n lineêre verloop van tyd bereken word op sterkte van die Pithagoras-Plato-tradisie. Die vraag is dan watter werklikheidswaarde die berekening van ouderdomme in die heelal het, byvoorbeeld van die sterreruimte, die aarde en fossiele. 
Geen berekening kan egter meer waar wees as die aannames waarvan uitgegaan word nie (Stafleu, 1987). Dit word in besonderhede deur Hooykaas (1959) se histories-kritiese studie van die beginsel van uniformitarisme bevestig. Hierdie teoretiese benaderings word nog meer onseker wanneer die bonatuurlike goddelike handelings in die sesdaagse skeppingstyd erken word.

Openbaar die kosmologie en die geologiese wetenskap God se werke? Die inhoude van sowel die geologiese wetenskap as die kosmologie openbaar die wonderbaarlike wysheid en grootsheid van die Skepper en Onderhouer van alles - waarvan die mens maar weinig begryp. In die Kosmologie kom 'n mens onder die indruk van die onbegryplike grootsheid van 'n ontsettende groot heelal met 'n wonderlik-aaneengeskakelde struktuur. God kan geëer en verheerlik word deur kennis te verkry in elke vertakking van die wetenskap.

\section{Geraadpleegde bronne}

AALDERS, G. Ch. 1949. Het boek Genesis: korte verklaring der Heilige Schrift. Kampen: Kok.

ADAM, B. 2004. Time. Cambridge: Polity.

CALVYN, J. 1937. De Catechismus van Calvijn. Vertaal deur J.J. Buskes. Baarn: Bosch \& Keuning.

CALVYN, J. 1970. Genesis: uitlegging van Johannes Calvijn. Vertaal deur S.O. Los. Goudriaan: De Groot.

COE, R.S., PRÉVOT, M. \& CAMPS, P. 1995. New evidence for extraordinary rapid change of the geomagnetic field during a reversal. Nature, 374:687692.

DAVIES, P. 1993. The Mind of God. London: Penguin.

DAVIES, P. 1995. About time: Einstein's unfinished revolution. London: Penguin.

FEYNMAN, R.P., LEIGHTON, R.B. \& SANDS, M. 1965. The Feynman lectures on physics: mainly mechanics, radiation and heat. Vol. 1. New York: Addison-Wesley.

FRY, I. 2000. The emergence of life on earth: a historical and scientific overview. New Brunswick: Rutgers University Press.

HAMBLIN, W.K. \& CHRISTIANSEN, E.H. 2004. Earth's dynamic systems. New Jersey: Prentice Hall.

HOOYKAAS, R. 1959. Natural law and divine miracle. Leiden: Brill.

LEAKY, R. \& LEWIN, R. 1999. The sixth extinction, biodiversity and its survival. Guernsey.

LEE, F.N. 1979. Creation and commission: a new translation and commentary on Genesis one through three. Tallahassee: Lee. Available: francisnigellee@dr-fnlee.org

MAYR, E. 1991. One long argument: Charles Darwin and the genesis of modern evolutionary thought. Cambridge: Harvard University Press.

NICKEL, J. 2001. Mathematics: is God silent? California: Ross House Books.

PEACOCKE, A. 1996. Nature of God, in nature, God and humanity. Pretoria: University of South Africa. 
PEARCEY, N.R. \& THAXTON, C.B. 1994. The soul of science: Christian faith and natural philosophy. Wheaton: Crossway Books.

POLKINGHORNE, J.C. 1991. One world: the interaction of science and theology. WBC.

PRIGOGINE, I. 1980. From being to becoming. San Francisco: Freeman.

SAVAGE, N. 2000. LEDs light the future. Technology review, 103:38-44.

SCHWARTZMAN, D. 2002. Life, temperature and the earth: the self-organizing biosphere. New York: Columbia University Press.

SILK, J. 1980. The Big Bang: the creation and evolution of the universe. San Francisco: Freeman.

STAFLEU, M.D. 1987. Theories at work. Langham: University Press of America.

STIX, G. 2001. The triumph of the light. Scientific American, 284:68-73.

STOKER, P.H. 2008. Wat is tyd? Tydskrif vir Christelike wetenskap, 44:89-113.

SUBBA RAO, N.S. 1999. Soil microbiology. Enfield: N.H. Science Publishers.

VORSTER, N. 2009. Die teologies-polemiese gerigtheid van Genesis 1-3: implikasies vir die gereformeerde leer oor erfsonde. In die Skriflig, 43(1): 95-117.

WARD, P.D. \& BROWNLEE, D. 2000. Rare earth: why complex life is uncommon in the universe. New York: Springer Verlag.

WOORDEBOEK VAN DIE AFRIKAANSE TAAL. 1956. Woordeboek van die Afrikaanse Taal. DI. 2: D-F. Pretoria: Die Staatsdrukker.

\section{Kernbegrippe:}

Genesis 1

onbeheerbare prosesse

ware kennis

wetenskaplike feite

wiskundige ordening

Key concepts:

dissipative systems

Genesis 1

mathematical order

scientific facts

true knowledge 
